Łukasz Cichocki ${ }^{1,2}$ () http://orcid.org/0000-0002-6567-3949

Aleksandra Wieczorek²,

Marta Hat $^{2}$ http://orcid.org/0000-0002-8721-9827

Katarzyna Pragnący ${ }^{1,2}$

Anna Depukat ${ }^{1,2}$

${ }^{1}$ Krakowska Akademia im. A.F. Modrzewskiego

${ }^{2}$ Ośrodek Edukacji, Badań i Rozwoju Szpitala Klinicznego im. Dr. J. Babińskiego w Krakowie

\title{
TRAUMA A ZDROWIE PSYCHICZNE - ANTONI KĘPIŃSKI IN MEMORIAM
}

\begin{abstract}
The trauma and mental health - Antoni Kępiński in memoriam

The article deals with the relationship between trauma experience and the area of mental health. The issues of possible consequences of trauma, its connections with selected psychopathological syndromes as well as possible mechanisms protecting mental health in the event of trauma are discussed. Particular emphasis was placed on the social determinants of trauma, both those favorable to its formation and those with protective effects. In the content of the article, an important place was devoted to the achievements of prof. Antoni Kępiński, precursor of research on trauma in Polish psychiatry.
\end{abstract}

Key words: trauma, mental health, resilience

Trauma - to słowo w ostatnich latach zaznaczyło wyraźnie swoją obecność w przestrzeni społecznej. Z jednej strony, w wielu sytuacjach jest używane nadmiarowo jako wyraz psychopatologizacji życia codziennego. Ludzie, mając ciężki dzień w pracy, konflikt rodzinny czy nieudany egzamin, są skłonni mówić: „ale miałam/em traumę”. Jest to ryzykowna strategia, ponieważ w morzu „traum” mogą zostać przeoczone traumy rzeczywiste, przeszłe bądź aktualne. I to jest druga strona medalu - nasze społeczeństwo stało się bardziej otwarte na uznanie i uszanowanie wpływu dramatycznych nieraz wydarzeń na życie, losy współcześnie nam żyjących, często po prostu nas samych. To, że w dyskursie społecznym pojawił się wyraźniej dramat Powstania Warszawskiego z rzezią Woli włącznie, a w ostatnim czasie temat rzezi wołyńskiej, w jakiejś mierze wynika z faktu, że mniej obawiamy się upiorów przeszłości i pozwalamy ofiarom, osobom dotkniętym niewątpliwą traumą mówić w bardziej otwarty sposób o tym, co ich spotkało. 
W dziedzinie psychiatrii podwaliny pod refleksję dotyczącą zagadnienia traumy kładł w Polsce, z końcem lat pięćdziesiątych XX wieku, Antoni Kępiński z zespołem (Adam Szymusik, Aleksander Teutsch, Maria Orwid, Roman Leśniak, Wanda Półtawska). Ich badania nad byłymi więźniami obozów koncentracyjnych zaowocowały m.in. licznymi publikacjami oraz sformułowaniem pojęcia syndromu KZ (Kępiński 1970). Opis prezentowanych przez badanych zaburzeń występujących po pobycie w obozie koncentracyjnym jest bardzo zbliżony do współczesnych definicji zaburzeń potraumatycznych (Rutkowski, Dębińska 2016). Obecnie w psychiatrii coraz więcej uwagi poświęca się traumie jako jednemu z czynników mających związek z etiologią innych, niż zaburzenia postresowe $\mathrm{w}$ wąskim tego słowa rozumieniu, zespołów psychopatologicznych. Uwagę zwracają zaburzenia, które mają głębszy charakter i bardziej przewlekły przebieg - psychozy, niektóre postacie zaburzeń osobowości i uzależnień, także zaburzeń afektywnych. Osoby cierpiące $\mathrm{z}$ tych powodów często doznały bądź doznawały przewlekle przez dłuższy czas traum o różnorodnym charakterze. W tym momencie można by zadać słuszne pytanie: czym zatem jest trauma? To, że może nią być pobyt w obozie koncentracyjnym, jest dla wszystkich oczywiste. W historiach przynoszonych przez pacjentów do psychiatrów, psychoterapeutów, opowiadanych przez klientów pracowników socjalnych są też inne, może nie tak jaskrawe, bardziej codzienne, nadal jednak bardzo raniące doświadczenia. W literaturze przedmiotu wymieniany jest najczęściej podział - zaproponowany przez Lenore Terr (1991) - na traumy typu I, które są wynikiem nagłego, niespodziewanego i krótkotrwałego wydarzenia zagrażającego życiu, oraz traumy typu II, które są wynikiem długotrwałych i powtarzających się udręk. Istnieje wiele możliwych scenariuszy, różne traumy mogą bowiem współistnieć, nakładać się na siebie. Spośród czynników mogących prowadzić do traumy wymieniane są czynniki „odludzkie”: przemoc fizyczna, emocjonalna, wykorzystanie seksualne, aborcja, zaniedbanie fizyczne/emocjonalne, porwanie, bycie ofiarą tortur, bycie świadkiem wydarzenia traumatycznego, ale także wydarzenia o charakterze zjawisk przyrodniczych lub wypadków: pożar, powódź, trzęsienie ziemi itd.

Trauma w różny sposób jest opracowywana przez aparat wewnątrzpsychiczny człowieka. Jej skutki zależą nie tylko od jej rodzaju i czasu trwania, lecz także od predyspozycji osobowościowych, otoczenia, w jakim człowiek się znajduje (tu m.in. możliwość uzyskania wsparcia). W analizie jej konsekwencji uwzględnia się także rolę czynników genetycznych (Auxemery 2012). One prawdopodobnie w jakiejś mierze decydują, że jedna osoba w wyniku traumy rozwinie zaburzenia o charakterze depresyjnym, a inna psychotycznym, a jeszcze inna nie doświadczy żadnych głębszych objawów psychopatologicznych.

\section{Trauma a psychoza}

W aktualnie obowiązującym, biopsychospołecznym modelu powstawania zaburzeń psychotycznych pozabiologiczne czynniki środowiskowe mają istotną rolę (Kotlicka-Antczak, Rabe-Jabłońska 2008). Jako potencjalny czynnik psychospołeczny rozwoju 
psychoz postrzegany jest czynnik tzw. wczesnej traumy. Badaniom związku traumy z psychozą towarzyszą jednak liczne problemy metodologiczne, a metaanaliza dostępnych badań ze względu na duże rozbieżności związane z definiowaniem traumy jest praktycznie niemożliwa. Część autorów postuluje nawet wyodrębnienie nowej kategorii zaburzeń psychotycznych - tzw. psychozy potraumatycznej (Morrison, Read, Turkington 2005). Podobnie wielu klinicystów ma doświadczenia odkrywania na kolejnych etapach wywiadu u pacjentów cierpiących z powodu zaburzeń psychotycznych traumatycznych wątków ich historii życiowej. W doświadczeniach własnych trudno ocenić wagę traumy, bo też jak porównywać traumę przeżyć wojennych czy bycia świadkiem okrucieństwa dokonanego na osobach najbliższych z traumą bycia wyśmiewanym w grupie rówieśniczej. Ale czy mamy prawo ocenić, że to drugie przeżycie miało mniejszą wagę dla świata wewnętrznego młodego człowieka czy przyszłych reakcji na inne stresory? Często nasi pacjenci dzielą się doświadczeniami traumy, która jest dla nas klinicystów trudna do udźwignięcia, występując tylko w roli słuchacza. Myślimy: „nic dziwnego, że ich świat rozpadł się na kawałki”, zarówno symbolicznie, jak i dosłownie. Jednak pomimo tych opisów i klinicznych doświadczeń nie można wyodrębnić prostego związku przyczynowo-skutkowego. Znamy przecież wielu pacjentów cierpiących z powodu zaburzeń psychotycznych bez doświadczeń traumatycznych w przeszłości i odwrotnie, ludzi, którzy doświadczyli „niewyobrażalnych cierpień” bez rozwinięcia psychozy. W tym momencie należy wspomnieć wyłaniające się z dostępnych badań pojęcie resilience/odporność (Werner 2005; Borucka, Ostaszewski 2008) oraz związek powstawania zaburzeń struktury i funkcji ośrodkowego układu nerwowego z czynnikami stresowymi, tzw. istotnymi wydarzeniami życiowymi (Read i in. 2001). $\mathrm{Na}$ rolę stresu w patogenezie zaburzeń psychotycznych wskazują także obserwacje dotyczące zwiększonej aktywności osi podwzgórze-przysadka-nadnercza (OPPN) już w okresie prepsychotycznym (Garner i in. 2005). Jak w takim razie wykorzystać dostępną wiedzę, aby zrozumieć, kiedy nasza odporność zostanie przełamana? Czy można opracować lepsze metody terapeutyczne czy nawet interwencje profilaktyczne, bazujące na koncepcji wzmacniania naszej odporności, a co za tym idzie ochrony przed czynnikami stresującymi zwiększającymi ryzyko rozwoju psychozy? Badacze i klinicyści stawiają w tym zakresie wiele pytań, szczególnie w aspekcie dowodów przemawiających za lepszą skutecznością oddziaływań psychoterapeutycznych u pacjentów z zaburzeniami psychotycznymi i doświadczeniem traumy w przeszłości (Morrison, Read, Turkington 2005; Kingdon, Turkington 2004) oraz specyfiki tych zaburzeń, np. wysokiego odsetka współwystępowania nadużywania substancji psychoaktywnych (Scheller-Gilkey i in. 2004). Kontynuacja badań w tym zakresie jest bardzo istotna, gdyż przyczynia się do lepszego poznania psychospołecznych uwarunkowań zarówno rozwoju psychoz, jak i pozytywnej adaptacji i tworzenia programów profilaktycznych i terapeutycznych. 


\section{Trauma a zaburzenia afektywne}

W patogenezie zaburzeń afektywnych, tj. choroby afektywnej dwubiegunowej i zaburzenia depresyjnego nawracającego, obok predyspozycji genetycznej i czynników neurobiologicznych istotną rolę patogenetyczną odgrywają wydarzenia życiowe. Wśród wydarzeń mogących mieć wpływ na występowanie zaburzeń afektywnych są: doświadczanie przemocy fizycznej, doświadczanie nadużyć emocjonalnych i zaniedbania emocjonalnego w dzieciństwie, doświadczanie nadużyć seksualnych, wczesna utrata lub rozłąka z jednym z rodziców lub opiekunów. Badanie przeprowadzone przez Hoertela z zespołem dowiodło, że wszystkie typy negatywnych doświadczeń w okresie dzieciństwa predysponują do popełnienia samobójstwa i są związane z wczesnym wiekiem pierwszej próby samobójczej (Hoertel i in. 2015). Doświadczenie przemocy fizycznej w okresie wczesnodziecięcym prawdopodobnie wpływa na niekorzystny przebieg choroby afektywnej dwubiegunowej (Daruy i in. 2011; Fisher, Hosang 2010).

Jednym z modeli teoretycznych próbujących wyjaśnić przyczynę zaburzeń afektywnych jest model predyspozycja-stres, zakładający, że początek choroby, okresy zaostrzeń i nawrotów wynikają z działania czynników wywołujących stres psychiczny na biologiczną predyspozycję do zaburzenia. Zgodnie z koncepcją poznawczą Aarona Becka, powstałą w latach 60. ubiegłego wieku, przyczyną depresji są dysfunkcjonalne przekonania, które stanowią triadę depresyjną: negatywna ocena samego siebie, otaczającego świata i przyszłości. Natomiast manię rozumiał jako lustrzane odbicie depresji. Według Becka dysfunkcjonalny sposób myślenia jednostki połączony z doświadczeniem traumatycznym, np. utratą bliskiej osoby, jest czynnikiem uwrażliwiającym na powstanie depresji. Z kolei koncepcja kindlingu (rozniecenia), której autorem jest Robert Post, była pierwszym modelem przebiegu choroby afektywnej dwubiegunowej. Model ten zakłada wpływ czynników psychospołecznych (stresorów) i neurobiologicznych w generowaniu epizodów choroby (Ferensztajn, Rybakowski 2012). Wydarzenia stresowe (np. wczesnodziecięce doświadczenie przemocy lub zaniedbania emocjonalnego) zostały nazwane pierwotnymi czynnikami uwrażliwiającymi. Do wystąpienia kolejnych epizodów choroby wystarczające są coraz słabsze zewnętrzne czynniki wyzwalające, a z czasem nawroty występują bez działania stresorów. Zjawisko kindlingu opisuje zależność między negatywnymi wydarzeniami w dzieciństwie a wystąpieniem depresji oraz choroby afektywnej dwubiegunowej w dorosłym życiu.

$\mathrm{W}$ pracy terapeutycznej, szczególnie z pacjentami z rozpoznaniem choroby afektywnej dwubiegunowej, uwaga kierowana jest na podłoże neurobiologiczne zaburzenia, co niejednokrotnie skutkuje leczeniem wyłącznie farmakologicznym, z pominięciem genezy psychospołecznej choroby. Nieco inaczej wygląda leczenie pacjentów z diagnozą epizodu depresyjnego czy zaburzenia depresyjnego nawracającego. Negatywne wydarzenia życiowe są często opisywane jako czynniki spustowe wystąpienia zaburzenia. W związku z tym pacjenci cierpiący z powodu zaburzeń depresyjnych znacznie częściej leczeni są dwutorowo: farmakologicznie i psychoterapeutycznie. 


\section{Trauma a zaburzenia osobowości}

Kolejną grupą zaburzeń psychicznych, w których etiologia doświadczeń traumatycznych odgrywa ważną rolę, są zaburzenia osobowości. Diagnoza ta może stanowić odrębną jednostkę kliniczną lub współwystępować z inną psychopatologią, jak uzależnienia, zaburzenia jedzenia, zaburzenia lękowe czy zaburzenia depresyjne. Rozważając etiologię zaburzeń osobowości, przyjmuje się również wzmiankowany wcześniej model biopsychospołeczny (Hornawska 2003). Wydaje się jednak, że w przypadku tych zaburzeń czynniki psychospołeczne są szczególnie istotne. Międzynarodowa Statystyczna Klasyfikacja Chorób i Problemów Zdrowotnych (ICD-10) wyróżnia odrębną kategorię diagnostyczną, tj. trwałą zmianę osobowości po katastrofach, czyli po przeżyciu sytuacji ekstremalnej (F62.0), w której jako doświadczenie traumatyczne wymienione zostały takie sytuacje stresujące, jak obóz koncentracyjny, tortury, katastrofy naturalne lub przedłużone narażenie na sytuację zagrażającą życiu (Pużyński, Wciórka 2000). Tutaj do zmiany osobowości dochodzi u człowieka z ukształtowaną osobowością, a jednak doświadczenie stresu może mieć tak potężne nasilenie, może być tak dojmujące, że potrafi zmienić osobowość. Nietrudno zatem wyobrazić sobie, że nie mniejsze konsekwencje mogą mieć urazy, które wystąpią u osób, których osobowość dopiero się kształtuje, czyli traumy powstające w dzieciństwie czy wczesnej adolescencji; szczególnie gdy dokonują się one w zaciszu domowym.

Istnieje wiele badań potwierdzających doniosłą rolę wczesnych doświadczeń traumatycznych w patologicznym rozwoju osobowości. Wśród szczególnie istotnych wymienia się powtarzające się w okresie dzieciństwa doświadczenia fizycznego i seksualnego wykorzystania, bycie świadkiem przemocy domowej oraz wczesnej separacji. Aby zobrazować te słowa liczbami, Anna Klatkiewicz (2011) za Weaver i Clum przytacza następujące dane: $76 \%$ pacjentów doświadczyło wykorzystania seksualnego w dzieciństwie (zazwyczaj w formie długotrwałego, powtarzanego doświadczenia, często ze strony członków rodziny), a 54\% było ofiarami bądź świadkami przemocy domowej. Dane te dotyczą jednego z podtypów zaburzeń osobowości, jakim jest osobowość z pogranicza (inaczej zwana osobowością borderline), w którym rola czynników traumatycznych została najlepiej przeanalizowana. Nie mniejsze znaczenie mają wczesnodziecięce doświadczenia relacji z pierwszymi opiekunami, szczególnie z matką, prowadzące do wytworzenia tzw. więzi i stylu przywiązania (Levy 2005; Clarkin 2006; Levy i in. 2006, 2014; Nickell i in. 2002). Opisane zostały różne style przywiązania, czyli sposoby budowania emocjonalnego związku z opiekunem, a które kształtują się od pierwszych dni życia. W psychopatologii znaczenie mają tzw. pozabezpieczne style przywiązania, które polegają na braku ufnej i bezpiecznej relacji z opiekunem. Szczególnie styl zdezorganizowany bardzo mocno, choć nieswoiście, koreluje $\mathrm{z}$ występowaniem różnorodnej psychopatologii, $\mathrm{w}$ tym również z zaburzeniami osobowości (Wallin 2011; Levy 2005; Levy i in. 2014). Kolejnym ważnym czynnikiem, który może działać traumatyzująco i przyczyniać się do rozwoju patologii osobowości (według badań w ponad $40 \%$ przypadków), jest tzw. negatywne środowisko rodzinne (Weaver, Clum 1993). W tych sytuacjach trauma nie osiąga aż tak ekstremalnych 
form jak przemoc seksualna czy fizyczna, ale dotyczy sfery psychofizycznej i z reguły jest długotrwała. Może się ona przejawiać w zaniedbywaniu potrzeb psychofizycznych dziecka bądź w stałym doznawaniu przez niego napięcia emocjonalnego panującego w rodzinie, w doświadczaniu stałych konfliktów czy nadmiernej kontroli. Poza samym faktem wystąpienia traumy w rozwoju psychopatologii istotne znaczenie ma również stopień jej nasilenia wyrażony np. wczesnym początkiem jej wystąpienia bądź jej naturą relacyjną (Yen i in. 2002). Trauma, szczególnie ta doświadczana wcześnie, zapisuje się na poziomie biologicznym. Dochodzi do długotrwałych zmian neuroanatomicznych, neuroendokrynnych oraz zmian związanych z neurotransmisją. Przykładowo osoby, które w dzieciństwie doświadczyły powtarzających się traum, mogą być agresywne lub impulsywne w dorosłości. Dzieje się tak, gdyż doszło do zmian w układzie oś podwzgórze-przysadka-nadnercza regulującej poziom kortyzolu, który z kolei oddziałuje m.in. na ciało migdałowate regulujące kontrolę impulsów (Watson i in. 2006; Heim, Nemoroff 2002).

Przytoczone dane naukowe dobrze korespondują z doświadczeniem klinicznym. W historiach życia pacjentów z zaburzeniami osobowości niezmiernie często znajdujemy różnorodne doświadczenia przemocy, nadużyć psychicznych, fizycznych i seksualnych. Jednak często ta historia traum pozostaje głęboko schowana, a pacjent zazwyczaj szuka pomocy specjalistów z powodu trudności w relacjach bądź nasilonych objawów psychopatologicznych, takich jak lęki, nawracające lub przewlekłe objawy depresyjne, nasilone zachowania autodestrukcyjne czy podejmowane próby samobójcze. Dopiero w czasie terapii stopniowo odkrywa się historia doświadczenia skrajnej przemocy fizycznej, np. w postaci takiego bicia dziecka, które doprowadziło nie tylko do siniaków, ale też do wstrząsu mózgu czy innego sadystycznego znęcania się nad dzieckiem poprzez głodzenie go lub, przeciwnie, wpychanie mu do ust wcześniej zwymiotowanego przez nie jedzenia albo wieloletniego kazirodczego wykorzystywania seksualnego, w wyniku którego doszło do poczęcia dziecka i kolejnej traumy w postaci przymusowej aborcji wykonanej u nastoletniej dziewczynki. Znamienne dla tego typu historii jest to, że zwykle nie są to pojedyncze zdarzenia, ale cała seria trudnych do wyobrażenia sobie doświadczeń. Czasami wnoszone przez pacjentów historie są tak przepełnione okrucieństwem i cierpieniem, że w samym klinicyście wyzwalają trudne do pomieszczenia uczucia przerażenia, złości, żalu czy emocjonalnego odrętwienia, dając niejako namiastkę doświadczeń, które były udziałem pacjenta. Tym, co dodaje sił i stanowi nadzieję w pracy z tak mocno straumatyzowanymi osobami, jest stosunkowo częste doświadczenie terapeutów, o którym pisze Edyta Biernacka, psychoanalityczka: „ktoś, kto został okrutnie skrzywdzony, potrafi zachować nadzieję i ryzykować obdarzeniem zaufaniem, a ktoś, w czyjej historii trudno znaleźć poważniejsze urazy, potrafi wyłącznie nienawidzić i mścić się" (Biernacka 2017). Taka postawa zaufania na płaszczyźnie klinicznej bardzo często przejawia się $\mathrm{w}$ istotnej poprawie funkcjonowania oraz poprzez stosunkowo szybkie ustępowanie objawów psychopatologicznych. 


\section{Trauma a uzależnienia}

Zanim osądzisz kogoś o to, że niszczy sam siebie, ważne żebyś pamiętał, że ludzie zazwyczaj nie chcą zniszczyć siebie. Oni próbują zniszczyć coś wewnątrz, coś, co nie jest ich częścią.

Osoby, które doświadczyły traumy, często próbują znaleźć sposób, aby złagodzić swoje cierpienie, szukają pomocy i wówczas bardzo często dochodzi do sięgnięcia po substancje psychoaktywne, np. alkohol. I mimo że używanie alkoholu czy innych substancji psychoaktywnych może powodować czasową ulgę objawową, to na dłuższą metę pogarsza sytuację, ponieważ uniemożliwia wyleczenie traumy. W badaniu Adverse Childhood Experiences (ACE) (Felitti i in. 1998) wykazano, że u osób, które w dzieciństwie doznały co najmniej czterech negatywnych doświadczeń, istnieje 4-12-krotnie większe ryzyko rozwinięcia uzależnienia od alkoholu i narkotyków oraz 2-4-krotnie zwiększone ryzyko uzależnienia od nikotyny. Nastolatki, które doświadczyły przemocy fizycznej lub seksualnej, trzy razy częściej niż osoby bez doświadczenia traumy relacjonują występowanie uzależnienia obecnie lub w przeszłości (Kilpatrick, Saunders, Smith 2003). Ponadto wyniki badań pokazują, że ponad 70\% adolescentów leczonych z powodu nadużywania substancji psychoaktywnych ma w wywiadzie doświadczenia traumatyczne (Funk i in. 2003; Deykin, Buka 1997). Badania wskazują na ewidentny związek między doświadczeniem traumy a nadużywaniem alkoholu i substancji psychoaktywnych. Należy pamiętać, że w przypadku osób zgłaszających się z problemem uzależnienia warto rozpoznać sytuację pod kątem występowania traumatycznych doświadczeń w przeszłości. Osoby podejmujące próby samoleczenia wrócą do uzależnienia, jeżeli nie zostanie właściwie rozpoznany problem, który maskuje uzależnienie.

Szacuje się, że:

- 25-75\% osób, które doświadczyły nadużycia i/lub przemocy, rozwinęły predyspozycję do nadużywania alkoholu (Gilchrist i in. 2003);

- rozpoznanie PTSD (zespół stresu pourazowego) zwiększa ryzyko uzależnienia od alkoholu;

- 52\% mężczyzn i 28\% kobiet potwierdza uzależnienie (Meisler 1996);

- osoby, które doświadczyły nadużycia seksualnego, mają wyższy wskaźnik używania alkoholu i narkotyków niż osoby, które nie miały takiego doświadczenia (Brecklin, Ullman 2002).

Praktyka kliniczna także wskazuje na fakt, że wśród osób, które doznały w swoim życiu traumatycznych wydarzeń, jest wysoki odsetek osób uzależnionych, a wśród osób uzależnionych wysoki odsetek osób, które doznały traumy. Życiorysy ludzi uzależnionych są często powiązane, a wręcz wykształcone przez traumę z okresu dzieciństwa. Jest to zjawisko na tyle powszechne, że wywiad od osób zgłaszających się do leczenia z problemem uzależnienia należałoby w każdym przypadku poszerzyć o informacje dotyczące wydarzeń traumatycznych, a do terapii uzależnienia włączyć interwencję 
skupioną na problemie traumy. Traumatyczne wydarzenia, które nie zostaną ujawnione w trakcie terapii uzależnienia, negatywnie wpływają na proces zdrowienia. Jeżeli pacjent wielokrotnie wraca do nałogu, to być może podstawowy problem nie tkwi w samym uzależnieniu i to jemu (pacjentowi) należy przyjrzeć się uważniej.

\section{Trauma a PTSD}

Diagnoza PTSD, która pojawiła się po raz pierwszy w klasyfikacji DSM III, nie opisała nowego fenomenu, tylko inaczej ujęła rzeczywistość znaną od zarania dziejów. Obecne badania wskazują, że objawy podobne do PTSD można odnaleźć nawet u wyższych ssaków, np. szympansów (Bradshaw i in. 2008). XX wiek dostarczył, niestety, bardzo wielu możliwości badania straumatyzowanych osób. W trakcie pierwszej wojny światowej sformułowano wobec nich diagnozę shell shock syndrome, druga wojna światowa przyniosła diagnozę syndromu KZ (Kępiński 1970). Diagnozę PTSD zawdzięczamy głównie obserwacjom i badaniom weteranów wojny w Wietnamie. Dość podobny zestaw objawów (niechciane powracanie traumatycznych wspomnień w postaci koszmarów sennych, nawracających wspomnień, obrazów związanych z traumą, unikanie bodźców przypominających, wzbudzenie - ciągłe napięcie, „pogotowie bojowe”) tworzy często przejmujący obraz osoby, która padła ofiarą wydarzenia/wydarzeń nie do zniesienia. W znanych nam z psychiatrycznej praktyki przykładach osób katowanych na UB, wywiezionych do Kazachstanu, będących świadkami lub ofiarami wielokrotnych nadużyć seksualnych zwraca uwagę - jako powtarzający się motyw - osamotnienie w tej sytuacji. Jest to o tyle ważne, że można znaleźć badania wskazujące na istotny protekcyjny wpływ dobrego, życzliwego otoczenia społecznego, które chroni ofiary traumy przed rozwojem PTSD (De Terte, Stephens, Huddleston 2014).

Częstość występowania (epidemiologia) PTSD jest bardzo zróżnicowana. Zależy od czynników geograficzno-historycznych, charakteru badanej populacji, odstępu czasu od momentu wystąpienia traumy do badania (Powers i in. 2014). Na przykład można przytoczyć dane, które mówią, że w grupie dzieci i młodzieży - ofiar wypadków samochodowych częstość występowania PTSD wynosiła 19,95\% (Dai i in. 2018), wśród ratowników z World Trade Center 19,9\% u mężczyzn i 25,9\% u kobiet (Remch i in. 2018), pracownic seksualnych w Soweto $39,6 \%$ (Coetzee i in. 2018).

Istnieją bardzo rozbieżne dane dotyczące związku między traumą a PTSD. Wiadomo, że nie wszystkie osoby, które doznały traumy, rozwiną objawy PTSD. Czy tak się wydarzy czy nie, zależy w dużej mierze od kontekstu społecznego.

\section{Kontekst społeczny}

Ważnym zagadnieniem w problemie trauma a zdrowie psychiczne pozostaje kwestia, jak to się dzieje, że jedni, doznając traumy, rozwijają objawy takich czy innych zaburzeń 
psychicznych, a drudzy nie. Użytecznym konstruktem do zrozumienia tych różnic może być pojęcie resilience. Zostało ono wprowadzone przez dwie osoby - Emmę E. Werner i Ruth S. Smith - jako wynik ich wieloletnich obserwacji 698 dzieci urodzonych na Hawajach w 1955 roku (Werner, Smith 2001). Ich badania wykazały, że mimo występujących u części z nich rozlicznych obciążeń peri- i postnatalnych, także o charakterze społecznym (rozpad rodziny, alkoholizm, skrajne ubóstwo itd.) wiele z nich daje sobie dobrze radę bez terapii w wieku 20 lat, a odsetek ten wzrasta w miarę upływu czasu. W badanej grupie jednym z istotniejszych czynników wspierających umiejętność radzenia sobie z traumatycznymi doświadczeniami było wsparcie społeczne od innych niż rodzinne środowisk. Innymi słowy, jeśli z jakichś względów rodzice okażą się niewydolni, jest szansa, że człowiek znajdzie wystarczające wsparcie w innej dorosłej osobie i/lub grupie rówieśniczej. W wyniku doznania wystarczającej ilości pozytywnych doświadczeń pojawiają się takie cechy/postawy, jak umiejętność rozwiązywania problemów, uwewnętrznienie poczucia kontroli, poczucie autonomii, wyższy poziom kompetencji społecznych, szukanie okazji do rozwoju. U pewnych osób w wyniku doznania traumy ostatecznie może zachodzić zjawisko nazywane wzrostem potraumatycznym, obserwowane m.in. w badaniach Dekel (Dekel, Mandl, Solomon 2013). Pewne intuicje w tym zakresie miał inny polski badacz - żyjący w podobnym czasie co Kępiński i dzielący z nim wiele doświadczeń Kazimierz Dąbrowski piszący o dezintegracji pozytywnej.

Trauma wpływa nie tylko na osoby bezpośrednio nią dotknięte, które same są jej ofiarami lub świadkami. Istnieje bardzo dużo doniesień o pośrednim wpływie traumy na drugie, a nawet trzecie pokolenie. Powinniśmy zarówno pamiętać, że wśród nas, w naszym społeczeństwie żyją bezpośrednie ofiary traum okresu wojny (Lis-Turlejska, Łuszczyńska, Szumiał 2016), ich dzieci i wnuki, jak i mieć świadomość faktu, że różnorodne zjawiska traumatyczne ciągle zachodzą. Taka świadomość skali i wagi problemu pozwala go z jednej strony dostrzegać, nie zaprzeczać jego istnieniu, ale też z drugiej strony nie banalizować i nadużywać. Z punktu widzenia społecznego warto pamiętać nie tylko o opisanych powyżej psychologicznych/psychiatrycznych skutkach traumy, lecz także o konsekwencjach somatycznych. Skutkują one np. zaburzeniami postrzegania własnego ciała (Sakson-Obada 2009), ale też problemami kardiologicznymi (Remch $\mathrm{i}$ in. 2018), zmianami o charakterze neurologicznym (Holmes 2018).

\section{Dlaczego „Antoni Kępiński in memoriam”?}

To nie przypadek, że niniejszy artykuł dotyczący związków traumy ze zdrowiem psychicznym jest poświęcony profesorowi Antoniemu Kępińskiemu. Jest kilka powodów, które sprawiają, że trudno pisać o traumie z perspektywy polskiego psychiatry, nie odnosząc się do spuścizny Profesora. Oprócz wspomnianego już kilkakrotnie syndromu KZ są to też osobiste, wojenne doświadczenia związane z uwięzieniem w okresie 1940-1943 w hiszpańskim obozie koncentracyjnym Miranda del Ebro. Profesor nie pisał o nich wiele. Bez wątpienia jednak wywarły one na niego wpływ zarówno jako na naukowca, 
terapeutę, jak i człowieka. Profesor, lubiąc stosować metafory, porównywał przerażający niekiedy świat psychozy do pobytu w obozie koncentracyjnym. Umiał nawiązać dobry, bezpośredni kontakt $\mathrm{z}$ byłymi więźniami obozu w Oświęcimiu (tak się nazywało go w czasach Profesora), najprawdopodobniej także dzięki własnym doświadczeniom z Miranda del Ebro. Ta umiejętność zaowocowała w przejmujących opisach zawartych w Rytmie życia, jednej z najbardziej poruszających pozycji dotyczących traumy w polskiej literaturze (nie tylko psychiatrycznej). Zaletą tej książki są rozliczne nawiązania do historii, filozofii, ale także socjologii, pozwalające lepiej zrozumieć zjawiska przemocy, traumy i ideologii, która do nich prowadzi. Jest zawarta w niej również nadzieja, że my, jako pojedyncze osoby, mamy wpływ na otaczające świat, na społeczeństwa, w których żyjemy. Dzięki temu wpływowi możemy starać się, aby poziom zranień, traumy w świecie się zmniejszał. Warunkiem jest wzajemne wspieranie się i umiejętność stawania w obronie tych, którzy są zagrożeni. W takiej postawie mogą się realizować postulaty Kępińskiego dotyczące psychiatrii aksjologicznej, w tym przede wszystkim szacunku do drugiego człowieka.

\section{Bibliografia}

Auxemery Y. (2012). Posttraumatic stress disorder (PTSD) as a consequence of the interaction between an individual genetic susceptibility, a traumatogenic event and a social context. „Encephale”, 38 (5): 373-380.

Biernacka E. (2017). Atak końca świata, czyli o terrorze nie-reprezentacji. Nadzieja w psychoanalizie. XIV Konferencja OLZON, Kraków, wrzesień 2017.

Borucka A., Ostaszewski K. (2008). Koncepcja resilience. Kluczowe pojęcia i wybrane zagadnienia. „Medycyna Wieku Rozwojowego", 12 (2 Pt 1): 587-597.

Bradshaw G.A., Capaldo T., Lindner L., Grow G. (2008). Building an inner sanctuary: Complex PTSD in chimpanzees. „J. Trauma Dissociation”, 9 (1): 9-34.

Brecklin L., Ullman S (2002). The roles of victim and offender alcohol use in sexual assaults: Results from the National Violence against Women Survey. „Journal of Studies on Alcohol and Drugs", 63 (1): 57-63.

Clarkin J. (2006). Conceptualization and treatment of personality disorders. „Psychotherapy Research", 16 (1): 1-11.

Coetzee J., Buckley J., Otwombe K., Milovanovic M., Gray G.E., Jewkes R. (2018). Depression and posttraumatic stress amongst female sex workers in Soweto, South Africa: A cross sectional, respondent driven sample. „PLoS One”, 13 (7): e0196759. doi: 10.1371/journal.pone.0196759. eCollection 2018.

Dai W., Liu A., Kaminga A.C., Deng J., Lai Z., Wen S.W. (2018). Prevalence of posttraumatic stress disorder among children and adolescents following road traffic accidents: A meta-analysis. „Can. J. Psychiatry”, 706743718792194. doi: 10.1177/0706743718792194.

Daruy-Filho L., Brietzke E., Lafer B., Grassi-Oliveira R. (2011). Childhood maltreatment and clinical outcomes of bipolar disorder. „Acta Psychiatr. Scand., 124 (6): 427-434. 
De Terte I., Stephens C., Huddleston L. (2014). The development of a three part model of psychological resilience. „Stress \& Health, 30 (5): 416-424.

Dekel S., Mandl C., Solomon Z. (2013). Is the Holocaust implicated in posttraumatic growth in second-generation Holocaust survivors? A prospective study. „J. Trauma Stress”, 26 (4): 530-533.

Deykin E.Y., Buka S.L. (1997). Prevalence and risk factors for posttraumatic stress disorder among chemically dependent adolescents. „Am. J. Psychiatry”, 154 (6): 752-757.

Meisler A.W. (1996). Trauma, PTSD, and substance abuse. „PTSD Research Quarterly”, 7 (4): 1-8. Felitti V.J., Anda R.F., Nordenberg D., Williamson D.F., Spitz A.M., Edwards V., Marks J.S. (1998). Relationship of childhood abuse and household dysfunction to many of the leading causes of death in adults: The Adverse Childhood Experiences (ACE) Study. „American Journal of Preventive Medicine",14 (4): 245-258.

Ferensztajn E., Rybakowski J. (2012). Etapy przebiegu choroby afektywnej dwubiegunowej. „Psychiatr. Pol.”; 46 (4): 613-626.

Fisher H., Hosang G. (2010). Childhood maltreatment and bipolar disorder: A critical review of the evidence. „Mind Brain”, 1: 750-785.

Funk R.R., Mc Dermeit M., Godley S.H., Adams L. (2003). Maltreatment issues by level of adolescent substance abuse treatment: The extent of the problem at intake and relationship to early outcomes. „Child Maltreat”, 8 (1): 36-45.

Garner B., Pariante C.M., Wood S.J. i in. (2005). Pituitary volume predicts future transition to psychosis in individuals at ultra-high risk of developing psychosis. „Biol. Psychiatry”, 58: 417-423.

Gilchrist E., Johnson R., Talriti R., Weston S., Beech A, Kebbell M. (2003). Domestic violence offenders: Characteristics and offending related needs. Findings. Home Office, London: 217.

Heim C., Nemeroff C.B. (2002). Neurobiology of early life stress: clinical studies. „Seminars in Clinical Neuropsychiatry", 7: 147-159.

Hoertel N., Franco S., Wall M.M., Oquendo M.A., Wang S., Limosin F. i in. (2015). Childhood maltreatment and risk of suicide attempt: A nationally representative study. „J. Clin. Psychiatry" 76: 916-923.

Holmes S.E., Scheinost D., DellaGioia N., Davis M.T., Matuskey D., Pietrzak R.H., Hampson M., Krystal J.H., Esterlis I. (2018). Cerebellar and prefrontal cortical alterations in PTSD: Structural and functional evidence. „Chronic Stress”, 2. doi: 10.1177/2470547018786390.

Hornawska E. (2003). Możliwość wykorzystania Kwestionariusza Temperamentu i Charakteru R.C. Cloningera w obszarze uzależnień od narkotyków - Raport; https://www.cinn.gov.pl/ portal?id=15\&res_id=216575 (dostęp: 21.11.2018).

Kępiński A. (1970). Tzw. „KZ-syndrom”. Próba syntezy. „Przegl. Lek., 1: 18-23.

Kilpatrick D.G., Saunders B.E., Smith D.W. (2003). Youth Victimization: Prevalence and Implications. Research in Brief. US Department of Justice, Office of Justice Programs, Washington, DC. Kingdon D.G., Turkington D. (2004). Cognitive Therapy of Schizophrenia. The Guilford Press, New York.

Klatkiewicz A. (2011). Traumatyczne zdarzenia w dzieciństwie a rozwój zaburzenia osobowości borderline. „Nowiny Lekarskie”, 80 (6): 484-492. 
Kotlicka-Antczak M., Rabe-Jabłońska J. (2008). Trauma okresu rozwojowego jako czynnik ryzyka rozwoju zaburzeń psychotycznych. Część I. Rozpowszechnienie zjawiska, problemy metodologiczne w badaniach naukowych. „Psychiatr. Psychol. Klin.”, 8 (2): 66-75.

Levy K. (2005). The implications of attachment theory and research for understanding borderline personality disorder. „Development and Psychopathology”, 17 (4): 959-986.

Levy K. i in. (2006). The mechanism of change in the treatment of borderline personality disorder and transferenced focused therapy. „Journal of Clinical Psychology”, 62 (4): 481-501.

Levy K. i in. (2014). Attachment theory and personality disorders, w: A. Danquah, K. Berry (red.), Attachment Theory in Adult Mental Health. Routledge, London-New York: 95-112.

Lis-Turlejska M., Łuszczyńska A., Szumiał S. (2016). Rozpowszechnienie PTSD wśród osób, które przeżyły II wojnę światowa w Polsce. „Psychiatr. Pol., 50 (5): 923-934.

Milon T., Davis R. i in. (2005). Zaburzenia osobowości we współczesnym świecie. Instytut Psychologii Zdrowia, Polskie Towarzystwo Psychologiczne, Warszawa.

Morrison A., Read J., Turkington D. (2005). Trauma and psychosis: Theoretical and clinical implications. „Acta Psychiatr. Scand.”, 112: 327-329.

Nickell A. i in. (2002). Attachment, parental bonding and personality disorders features in young adults. „Journal of Personality Disorders”, 16 (2): 138-159.

Powers M.B., Warren A.M., Rosenfield D., Roden-Foreman K., Bennett M., Reynolds M.C., Davis M.L., Foreman M.L., Petrey L.B., Smits J.A. (2014). Predictors of PTSD symptoms in adults admitted to a Level I trauma center: A prospective analysis. „J. Anxiety Disord., 28 (3): 301-309.

Pużyński S., Wciórka J. (red.) (2000). Klasyfikacja zaburzeń psychicznych i zaburzeń zachowania wg ICD-10. Opisy kliniczne i wskazówki diagnostyczne. Uniwersyteckie Wydawnictwo Medyczne „Vesalius”, Instytut Psychiatrii i Neurologii, Kraków-Warszawa.

Read J., Perry B.D., Moskowitz A., Connolly J. (2001). The contribution of early traumatic events to schizophrenia in some patients: A traumagenic neurodevelopmental model. „Psychiatry”, 64: 319-345.

Remch M., Laskaris Z., Flory J., Mora-McLaughlin C, Morabia A. (2018). Posttraumatic Stress Disorder and Cardiovascular Diseases: A Cohort Study of Men and Women Involved in Cleaning the Debris of the World Trade Center Complex. „Circ. Cardiovasc. Qual. Outcomes”,11 (7): e004572. doi: 10.1161/CIRCOUTCOMES.117.004572.

Ross C.A. (2005). Schizophrenia: Innovations in Diagnosis and Treatment. The Haworth Press, New York.

Rutkowski K., Dembińska E. (2016). Powojenne badania stresu pourazowego w Krakowie. Część I. Badania do 1989 roku. „Psychiatr. Pol.”, 50 (5): 935-944.

Sakson-Obada O. (2009). Trauma jako czynnik ryzyka dla zaburzeń ja cielesnego. „Przegląd Psychologiczny", 52 (3): 309-326.

Scheller-Gilkey G., Moynes K., Cooper I. i in. (2004). Early life stress and PTSD symptoms in patients with comorbid schizophrenia and substance abuse. „Schizophr. Res., 69: 167-174.

Suzuki A. i in. (2011). The brain-derived neurotropic factor Val66Met polymorphism modulates the effects of parental rearing on personality traits in healthy subjects. „Gens, Brain and Behavior", 10: 386-391. 
Terr L.C. (1991). Childhood traumas: An outline and overview. „Am. J. Psychiatry”, 148 (1): 10-20.

Wallin D. (2011). Przywiązanie w psychoterapii. Wydawnictwo Uniwersytetu Jagiellońskiego, Kraków.

Watson S. i in. (2006). Association between childhood trauma and dissociation among patients with borderline personality disorder. "Australian and New Zealand Journal of Psychiatry”, 40: 478-481.

Weaver T.L., Clum G.A. (1993). Early family environments and traumatic experiences associated with borderline personality disorder. „J. Consult. Clin. Psychol., 61 (6): 1068-1075.

Werner E.E., Smith R.S. (2001). Journeys from Childhood to Midlife: Risk, Resilience, and Recovery by Emmy E. Werner and Ruth S. Smith. Cornell University Press, New York, NY.

Werner E.E. (2005). What can we learn about resilience from large-scale longitudinal studies?, w: S. Goldstein, R.B. Brooks (red.), Handbook of Resilience in Children. Springer, Boston, MA: 91-105.

Yen S. i in. (2002). Traumatic exposure and posttraumatic stress disorder in borderline, schizotypal, avoidant, and a obsessive-compulsive personality disorders: Finginges from the collaborative longitudinal personality disorders study. „The Journal of Nervous and Mental Disease”, 190 (8): 510-518. 